\title{
Casting a Shadow of Doubt over the GWAS Parade
}

\author{
Francis J. McMahon ${ }^{1 *}$ \\ ${ }^{1}$ Human Genetics Branch and Genetic Basis of Mood and Anxiety Disorders \\ Section, National Institute of Mental Health Intramural Research Program.
}

*Correspondence: Francis J. McMahon, Email: francis.mcmahon@ nih.gov.

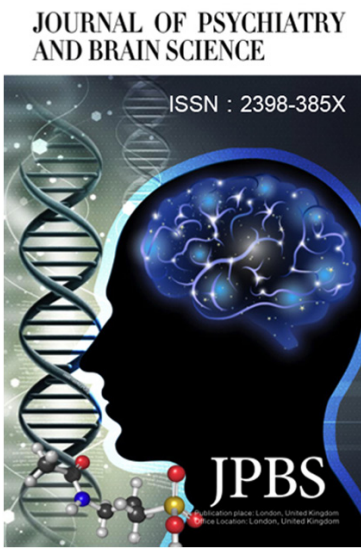

http://jpbs.qingres.com

\section{fOPEN ACCESS}

DOI: 10.20900/jpbs.20170014(S1-S8)

Received: July 17, 2017

Accepted: September 11, 2017

Published: October 12, 2017

Copyright: ๑2017 Cain et al. This is an open access article distributed under the terms of the Creative Commons Attribution License, which permits unrestricted use, distribution, and reproduction in any medium, provided the original author and source are credited.
Jonathan Pritchard is a careful thinker with a knack for recognizing inconvenient truths. His article proposing that common, complex diseases might actually comprise many different conditions caused by individually rare genetic events ${ }^{[1]}$, nicely anticipated the "rare variant revolution" initiated by the discovery of $\mathrm{CNVS}^{[2]}$ that continues to gain steam in the era of whole exome and whole genome sequencing.

So when Pritchard proposes a new idea, we are well advised to listen. In a paper co-authored with Evan Boyle and Yang Li, Pritchard now proposes that gene regulatory networks are so interconnected that just about any gene expressed in a disease-relevant tissue may affect core disease genes and contribute to disease heritability. This "omnigenic" model is not totally new. The similar and longstanding "infinitesimal model" has cast a periodic shadow over the eternal sunshine of GWAS for several years ${ }^{[3-5]}$. One of the earliest integrative genomics papers by Eric Schadt and colleagues showed that most genes expressed in the liver were, in some sense, related to type II diabetes ${ }^{[6]}$. And David Goldstein has long raised concerns about the often strained relationship between GWAS hits and biology ${ }^{[7]}$.

My own view is that the omnigenic model is probably a worst case scenario. GWAS have still provided the best leads we have in understanding the biological basis of psychiatric disorders such as schizophrenia, bipolar disorder, or major depression ${ }^{[8]}$. If we focus on the most reproducible hits with the largest effect sizes, especially those that act as expression QTLs for nearby genes ${ }^{[9]}$, then we have a good chance of identifying etiologically relevant pathways. Progress may not be quick or linear, but as long as the initial association results are solid, further work will ultimately lead us in the right directions.

\section{REFERENCES}

1. Pritchard JK. Are rare variants responsible for susceptibility to complex diseases? Am J Hum Genet. 2001 Jul; 69(1): 124-137.

2. Malhotra D, Sebat J. CNVs: harbingers of a rare variant revolution in psychiatric genetics. Cell. 2012 Mar 16; 148(6): 1223-1241.

3. Johnson $\mathrm{T}$, Barton $\mathrm{N}$. Theoretical models of selection and mutation 
on quantitative traits. Philos Trans R Soc Lond B Biol Sci. 2005; 360(1459): 1411-1425.

4. Gibson G. Rare and common variants: twenty arguments. Nat Rev Genet. 2011; 13(2): 135.

5. Lango Allen H, Estrada K, Lettre G, Berndt SI, Weedon MN, Rivadeneira F, et al. Hundreds of variants clustered in genomic loci and biological pathways affect human height. Nature. 2010 Oct 14; 467(7317): 832-838.

6. Zhong $\mathrm{H}$, Beaulaurier J, Lum PY, Molony C, Yang X, MacNeil DJ, et al. Liver and adipose expression associated SNPs are enriched for association to type 2 diabetes. PLoS Genet. 2010; 6(5): e1000932.
7. Need AC, Goldstein DB. Whole genome association studies in complex diseases: where do we stand? Dialogues Clin Neurosci. 2010; 12(1): 37-46.

8. Sullivan PF. The psychiatric GWAS consortium: big science comes to psychiatry. Neuron. 2010 Oct 21; 68(2): 182-186.

9. Hernandez DG, Nalls MA, Moore M, Chong $S$, Dillman A, Trabzuni D, et al. Integration of GWAS SNPs and tissue specific expression profiling reveal discrete eQTLs for human traits in blood and brain. Neurobiol Dis. 2012 Jul; 47(1): 20-28. 